\title{
Plasticity in the Sclerites of a Gorgonian Coral: Tests of Water Motion, Light Level, and Damage Cues
}

\author{
JORDAN M. WEST \\ Section of Ecology and Systematics, Corson Hall, Cornell University, Ithaca, New York 14853-2701
}

\begin{abstract}
The gorgonian coral Briareum asbestinum contains skeletal elements (sclerites) that vary in length and density within and among local populations. Data from previous work suggested that the sclerite compositions of colonies may be altered in response to environmental cues such as predator damage, water motion, and light level. To test these hypotheses, colonies from shallow reefs were transplanted to racks at a single location where the three environmental factors of interest were artificially manipulated. After 9-14 weeks of growth, sclerite morphologies and densities had not changed in response to shading or to water-motion reductions that mimicked deep-water conditions. However, colonies did respond significantly to two types of simulated predator damage. Following tip amputation, sclerites in the regenerated tips of damaged colonies were shorter and more dense than in the controls. In contrast, mid-branch scarring caused colonies to produce longer sclerites at lower densities. Since long sclerites deter feeding by predatory snails, the increase in sclerite length in response to scarring of midbranch regions may function as an inducible defense.
\end{abstract}

\section{Introduction}

Phenotypic plasticity-or differential phenotypic expression of a genotype under varying environmental conditions-has been a subject of increasing interest to evolutionary ecologists since Bradshaw's (1965) extensive review (e.g., Bradshaw, 1974; Via and Lande, 1985; Schlichting, 1986; Stearns, 1989; Scheiner, 1993). Although plasticity can be nonadaptive or maladaptive, researchers have been primarily interested in adaptive plasticity as a mechanism by which organisms cope with

Received 18 September 1996; accepted 6 February 1997

Present address: University of Washington, Friday Harbor Laboratories, 620 University Road, Friday Harbor, Washington 98250 changing environments. Adaptive plasticity is especially well documented in plants, for which the literature contains numerous examples of induced responses to physical factors such as shade (Turesson, 1920), desiccation (Harlan, 1945), soil fertility (Sorensen, 1954), temperature (Mooney and West, 1964), and water stress (Roy and Mooney, 1982). Bradshaw (1965) reasoned that plasticity should often be favored in plants because they are sessile organisms whose autotrophic lifestyle requires that they inhabit relatively open spaces where they may be exposed to environmental extremes. When the scale of temporal variability is shorter than the lifespan of the organism, or where spatial variability is at a scale smaller than the dispersal range of the organism, adaptive plasticity is a viable strategy.

In marine habitats, sessile colonial invertebrates, such as scleractinian and gorgonian corals, share many characteristics with plants. Colonies are permanently sessile, often with upright branched growth forms (Barnes, 1987); and many corals depend on symbiotic algae (zooxanthellae) for a large proportion of their energy (Muscatine, 1974; Muscatine et al., 1975; Svoboda, 1978; Sebens, 1987) and are thus largely autotrophic. In addition, populations with wide distributions are routinely exposed to variation in abiotic factors such as light level (McCloskey and Muscatine, 1984; Miles, 1991), wave exposure (de Weerdt, 1981; Sebens, 1984), and sedimentation rate (Foster, 1979). Indeed, variation in colony morphology or physiology in response to temperature, depth, or water movement has been documented in sponges (Bavestrello et al., 1993), scleractinian corals (Wijsman-Best, 1974; Foster, 1979; Lesser et al., 1994), and gorgonian corals (Grigg, 1972; West et al., 1993).

In both plants and corals, inducible defenses represent a special category of adaptive plasticity that involves biotic rather than abiotic cues. Defined as environmentally triggered phenotypic responses that defend against spe- 
cific biotic selective agents (Adler and Harvell, 1990), inducible defenses have emerged as prominent phenomena only in the past 20 years. A variety of plant responses to real or simulated herbivore damage include increased morphological defenses such as spines or resistant growth forms (Young, 1987; Lewis et al., 1987) and production of physicochemical deterrents such as polyphenolic compounds, alkaloids, or silica (McNaughton and Tarrants, 1985; Schultz, 1988; Van Alstyne, 1988; Baldwin and Ohnmeiss, 1993). Among colonial invertebrates, various species respond to the presence of competitors by producing agonistic weaponry such as digestive filaments, stolons, or sweeper tentacles (Ivker, 1972; Francis, 1973; Lang, 1973; Wellington, 1980; Sebens and Miles, 1988; Harvell and Padilla, 1990; Miles, 1991). However, although predator-induced defenses, such as spines and helmets, have been documented in various clonal freshwater invertebrates (e.g., Gilbert and Stemberger, 1984; Havel, 1986), examples of induced defenses against predators in colonial marine invertebrates (Harvell, 1984) are surprisingly rare.

In the Caribbean coral Briareum asbestinum (Gorgonacea), both biotic and abiotic environmental agents may contribute to plastic variation in skeletal features. Unlike the hard corals with their massive calcium carbonate skeletons, gorgonian corals consist of a central axis surrounded by an outer cortex of a soft, polyp-bearing matrix, the structural integrity of which is maintained by small $(0.2-1.2 \mathrm{~mm})$, calcitic skeletal elements (sclerites) (Fig. 1). Within and among local populations, $B$. asbestinum colonies vary significantly in the mean lengths and densities of their sclerites. Furthermore, a reciprocal transplant of colonies between shallow and deep sites indicated that sclerite morphology is phenotypically plastic in response to one or more environmental cues (West et al., 1993; West, 1996).

One such cue may be damage from predators. In addition to skeletal support, sclerites fulfill a second role as structural defenses against predators. B. asbestinum contains ichthyodeterrent, diterpene secondary compounds (Pawlik et al., 1987), and predation by fishes appears to be minimal (C. D. Harvell, unpubl. data). However, the gastropod Cyphoma gibbosum is a major predator of gorgonian corals (Kinzie, 1970; Lasker and Coffroth, 1988; Lasker el . 1988) and is an important source of damage to $B$. asbestimum (Hazlett and Bach, 1982). $C y$ phoma gibbosum contains biotransformation enzymes capable of detoxifying B. asbestinum allelochemicals (Vrolijk and Targett, 1992) and consumes artificial foods containing $B$. asbestinum extracts and pure compounds just as readily as it consumes control foods (C. D. Harvell, unpubl. data). Therefore, the sclerites of $B$. asbestinum may be its only defense against this predator, such that differences in skeletal composition will correlate

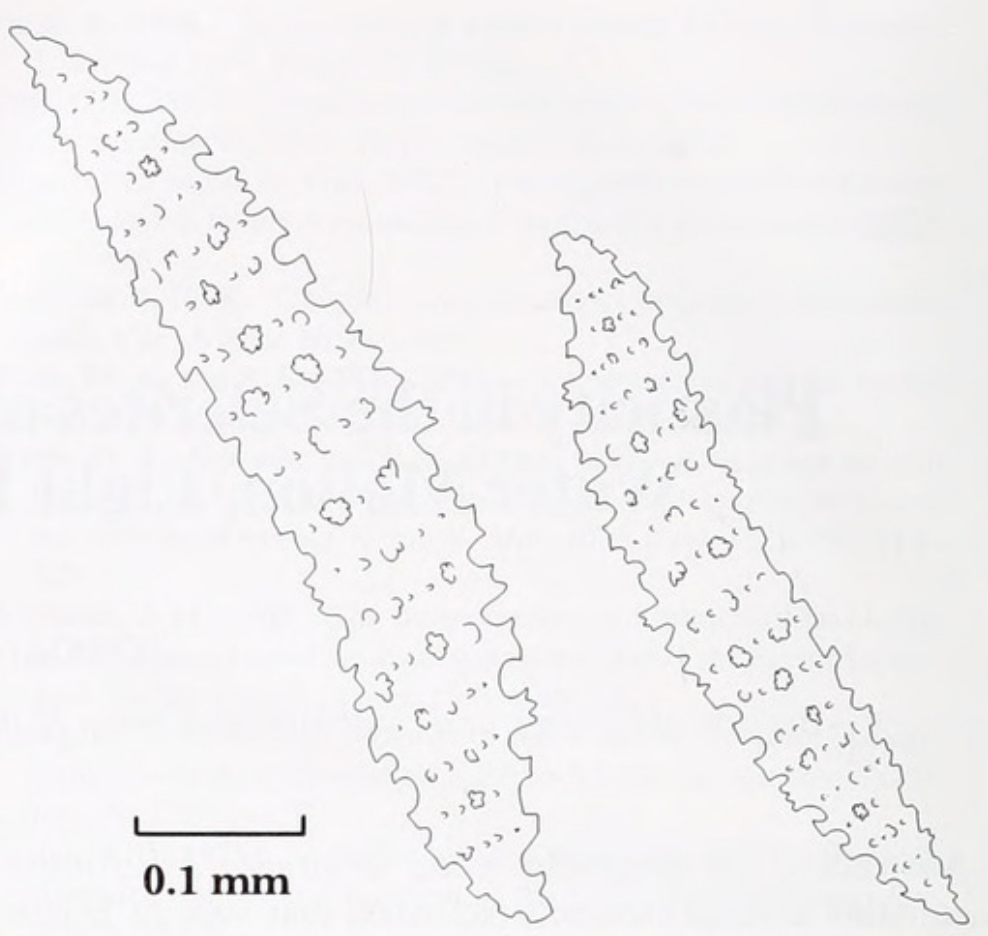

Figure 1. Briareum asbestinum. Diagram of typical sclerites, showing the $23 \%$ difference in mean sclerite length that is inducible and affects snail feeding (West, 1996). Colonies within the same local population can differ in mean sclerite length by as much as $32 \%$ (West, 1996).

with the ability of colonies to deter snail feeding (West et al., 1993; West, 1996). As sclerites increase in size, they render artificial foods less palatable to C. gibbosum (Van Alstyne and Paul, 1992; West et al., 1993; West, 1996). Hence, the inducibility of long, defensive sclerites as a reaction to damage would be a potentially advantageous plastic response.

In addition to biotic induction, sclerite plasticity among $B$. asbestinum populations may also be cued by changing abiotic conditions. At two islands in the Caribbean, colonies of $B$. asbestinum are distributed along a depth gradient of 1-30 m. At the shallow end of the gradient, sclerites are short and of high density, whereas deep colonies contain sclerites that are long and of low density. Sclerite length and density within colonies are negatively correlated, such that colonies with both long and densely packed sclerites do not occur (West et al., 1993; West, 1996). Although biotic induction by a patchily distributed predator could account for variability within sites, the pattern of increasing sclerite length with depth cannot be explained solely by the presence of predators. Snails are indeed present at all of my study sites, but their densities and damage actually decrease with depth, whereas sclerite length increases with depth (West, 1996; C. D. Harvell, unpubl. data). Hence, largerscale patterns of sclerite variability with depth may be generated by abiotic environmental factors.

Along the depth cline, declining light penetration and 
water motion both show some degree of correlation with sclerite variation (West, 1996). Both factors might affect skeletal composition in different ways and might function as cues that induce a plastic response in sclerite length and density. Observed correlations between sclerite variation and percent penetration of photosynthetically active radiation (West, 1996) may be related to effects of light on colony growth rates (C. D. Harvell, unpubl. data), because gorgonians depend on their symbiotic zooxanthellae for most of their energy (Sebens, 1987). In addition, strong correlations between sclerite variation and water motion (West, 1996) may relate to the function of sclerites as skeletal support structures. The sclerites of $B$. asbestinum act as rigid reinforcing points of attachment within the soft matrix, providing resistance to deformation; both smaller sclerites and greater densities of sclerites confer greater stiffness (Wainwright et al., 1976; Koehl, 1982; Palumbi, 1986). Therefore, colonies may display depth-related shifts in skeletal composition according to water motion and light level cues.

In this study, I tested the ability of one biotic agent (predator damage) and two abiotic factors (water motion and light) to induce skeletal modifications in the soft coral $B$. asbestinum. Because the large collections needed for this work would have denuded the sparsely populated deep reefs at my sites, I focused on shallowwater B. asbestinum. To examine separately the effect of each type of cue, two large transplant experiments were conducted in which colonies from a shallow population were grown on racks at a single site where water motion, light, and damage were manipulated under controlled conditions. I hypothesized that shallow-water colonies subjected to reduced water motion and reduced light (simulating deep-water conditions) and colonies subjected to mechanical scarring (simulating predator damage) should respond in each case by producing longer sclerites at lower densities compared to controls.

\section{Materials and Methods}

\section{Experiment I: water motion and damage}

To assess whether differences in water motion and simulated predator damage would induce plastic changes in sclerite composition, I conducted a transplant experiment at San Salvador, Bahamas, from 1 June to 3 August, 1991. Branches from a shallow (1-3 m) population of Briareum asbestinum were transplanted to racks on which they reattached themselves and grew as independent new colonies. The racks were arrayed at a single location where water motion and damage were varied. The 12 racks were constructed according to a design modified from West et al. (1993). Each rack consisted of an acrylic plate, dimensions $30.0 \times 23.0 \times 2.5 \mathrm{~cm}$, that snapped into an aluminum angle frame. Each plate accommodated 12 ( 2 rows of 6 ) colonies, each inserted into a recessed well and secured with cushioned cable ties to an acrylic post.

The racks were rigidly affixed to cement blocks at a shallow $(3 \mathrm{~m})$ site that exposed the colonies to high-energy waves and surge. Water motion was reduced inside half of the racks by clear, small-mesh $(0.20 \mathrm{~mm})$ nylon screening that was attached to form walls $15 \mathrm{~cm}$ tall (Fig. $2)$. Water motion inside control and walled racks was quantified by recording the percent dissolution of plaster of Paris (a water-motion index) using methods adapted from Muus (1968), Doty (1971), Day (1977), Bushek (1988), and Jokiel and Morrissey (1993). For this integrated relative measure of water movement due to current velocities and turbulence (Doty, 1971), I measured the weight loss of five replicate plaster domes $(24 \mathrm{~g})$ for each rack type over a 24 -h period (see West, 1996, for a more detailed description). When compared with measurements made at various other $B$. asbestinum habitats, the reduction in water motion between walled and control racks was found to be similar to differences in water motion between colonies growing deep within crevices and colonies out on the open reef flat. Naturally occurring $B$. asbestinum colonies from these habitat types differ significantly in sclerite composition (West, 1996).

All racks were fitted with clear, large-mesh $(2.5 \mathrm{~cm})$ roofs that afforded protection from disturbance by fishes without affecting light penetration. Furthermore, placement of the racks in a sand patch several meters from the reef prevented discovery of the colonies by benthic predators (confirmed through weekly monitoring). Light measurements with a quantum/radiometer/photometer (LI-185B with LI-192SB underwater sensor; LI-COR, Inc., Lincoln, Nebraska) showed that penetration of photosynthetically active radiation (PAR) was the same inside and outside of walled and control racks. During the experiment, the walls and roofs were scrubbed regularly with a stiff brush to remove fouling organisms.

The effects of damage due to simulated predation or breakage were tested by assigning each colony to one of three damage treatments: (1) control; (2) scar; and (3) tip amputation (Fig. 2). The controls were left undamaged. The scar treatment simulated damage by Cyphoma gibbosum (Gastropoda), a predator that is typically found on the middle region of colony branches (Harvell and Suchanek, 1987; Gerhart, 1990), where it can rasp the cortex as deep as the axis (Harvell and Suchanek, 1987; West, 1996). Hence, starting about $3 \mathrm{~cm}$ from the tip and working downward, I damaged the mid-regions of colonies by gouging them to the axis to create a $1-\times 3-\mathrm{cm}$ scar. Finally, tip amputation involved severing the top $1 \mathrm{~cm}$ of the colony to simulate predation or breakage. Briareum asbestinum is a preferred prey species of $\mathrm{Her}$ - 


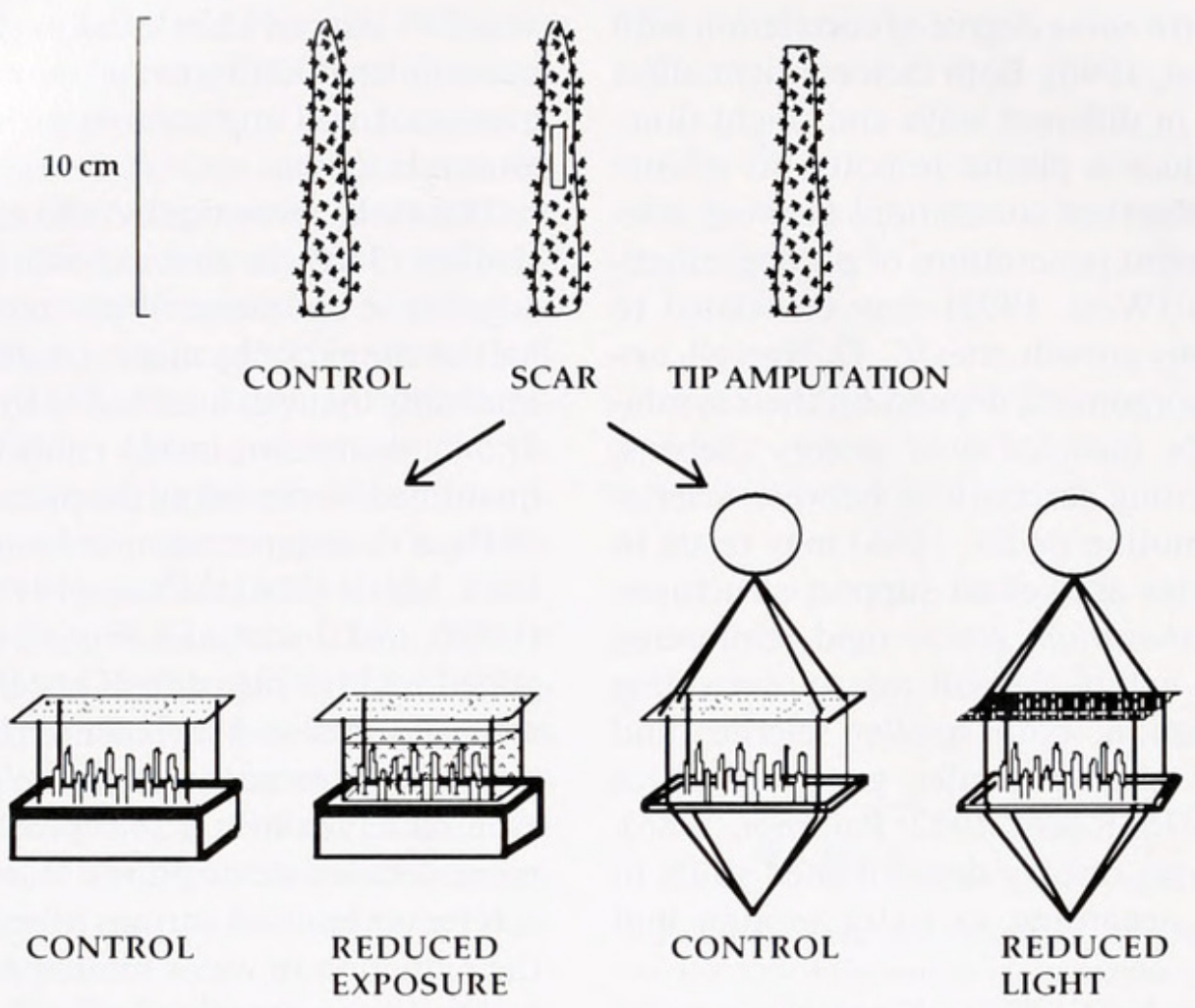

\section{EXPERIMENT I}

EXPERIMENT II

Figure 2. Design of transplant experiments to test sclerite plasticity in Briareum asbestinum. Damage types: control $=$ undamaged, $\mathrm{scar}=1-\times 3-\mathrm{cm}$ gouge, tip $=1-\mathrm{cm}$ tip amputation. Experiment $\mathrm{I}($ exposure and damage): control and reduced exposure racks. Experiment II (light and damage): control and reduced light racks.

modice carunculata (Polychaeta), which commonly feeds by a characteristic removal of branch tips (Vreeland and Lasker, 1989). Thus, tip removal may be similar to the damage inflicted on colonies by worms. Yet, tip removal also lays bare a cross-sectional area of the colony, so amputation also mimics the end product of breakage resulting from heavy wave action. The original cortex material from each scar or tip amputation was preserved in $70 \%$ ethanol for later analysis.

Because the number of samples was large, the experiment was set up over 2 days. Each day, 72 undamaged branches, $10 \mathrm{~cm}$ long, were collected from a shallow (1$3 \mathrm{~m}$ ) reef of high wave energy. To maximize the genetic diversity of the collection, divers swam linearly along the reef and sampled single branches from colonies that were separated from any others by at least $3 \mathrm{~m}$. After collection, the branches were suspended in flow-through mesh bags from the side of the boat at the nearby transplant site. They were then assembled onto racks (equal numbers of damage types, randomized with respect to rack position) inside large containers of seawater in the boat, and each completed rack was immediately conveyed to the transplant site below. Virtually all branches began extending their polyps within $2 \mathrm{~h}$ of transplantation. Within a few weeks, the branches had attached them- selves to the racks and were growing as independent colonies. The colonies were allowed to heal and grow for 9 weeks, and survival exceeded $95 \%$. During the experiment, more than $50 \%$ of the colonies increased in height by $0.1-1.5 \mathrm{~cm}$; and all survivors showed positive growth in the sense that they produced new cortex material that encrusted their supportive posts and ties, filled in their scars, and covered over their tip wounds. At the end of 9 weeks, the colonies were collected and preserved in $70 \%$ ethanol until they could be processed in the laboratory.

\section{Experiment II: light and damage}

To test the effects of reduced light and colony damage, another transplant experiment was conducted from 7 February to 20 April, 1991. The methods were the same as those described for experiment I with the following modifications. Branches were collected from throughout a shallow, relatively calm bay and transplanted to a 12$\mathrm{m}$ location nearby. The colonies were subjected to the same three types of damage and were distributed similarly within the racks, but instead of walls, half of the racks were fitted with roofs made of a double layer of dark window screening (Fig. 2). This screening (1-mm 
mesh) reduced the light levels typical of 12-m depth to light levels typical of $30-\mathrm{m}$ depth (J. Miles, pers. comm., calibrated with Li-Cor light meter). The other half of the racks (controls) were fitted with roofs made of clear nylon netting (2.5-cm mesh) to discourage disturbance by fishes without affecting light penetration. The roofs were scrubbed regularly to remove fouling organisms.

To prevent access by benthic predators, the racks were floated about $2 \mathrm{~m}$ above the reef flat with steel cables and subsurface buoys. Because the racks could move with the currents, the effects of water motion were moderated. Positive growth of the transplanted colonies was similar to that of experiment I, and colony survival again exceeded $95 \%$. After 14 weeks, the colonies were preserved in $70 \%$ ethanol until they were processed in the laboratory.

\section{Sclerite measures}

At the end of each experiment, subsets of 1-3 colonies per damage type per rack were measured. Sclerite lengths were recorded in the laboratory with the MORPHOSYS image analysis program (Meacham and Duncan, 1990; version 1.26). For colonies subjected to scarring or tip amputation, both the original cortex material collected when the colonies were damaged ("before" sample) and newly regenerated material from the healed wound ("after" sample) were analyzed. In experiment I, a midbranch cortex sample from the side opposite the scar ("opposite" sample) was also analyzed to see whether the response to scarring was regionwide. Hence, cortex material was sampled from the following regions of the colonies: (1) tip region of damaged colonies, before and after amputation; (2) mid-branch region of damaged colonies, before, after, and opposite the scars; and (3) midbranch and tip regions of control colonies at the end of the experiment (after).

For sclerite length measurements, cortex subsamples were taken from the edges of scars before and after healing, from original and healed tips at a distance of $1 \mathrm{~cm}$ down from the apex, and from the same locations (by distance from the apex) in the controls. In each case, two small (3-4 $\left.\mathrm{mm}^{3}\right)$ cortex samples were excised, and the organic matter was dissolved away with a solution of $2.6 \%$ sodium hypochlorite. The isolated sclerites were rinsed and distributed in their entirety across six slides (three slides per tissue sample). Video images of the first 4 intact sclerites encountered per slide were measured, for a mean of 24 sclerites per region per colony.

From the same regions of the colonies, the proportion of cortex weight consisting of sclerites (the sclerite weight fraction, a measure of density) was estimated according to Harveli and Suchanek's (1987) protocol. From midbranch regions, a $1-\times 3-\mathrm{cm}$ cortex scraping at the edge of the original scar (or from the middle region of the control) was taken, and from tip regions, the distal $1 \mathrm{~cm}$ of cortex material was used in all cases. The samples were separately dried for $24 \mathrm{~h}$ at $60^{\circ} \mathrm{C}$ and weighed; a drying test on a subset of samples showed that they did not continue to lose weight after $24 \mathrm{~h}$. Each sample was then ashed in a muffle furnace at $450^{\circ} \mathrm{C}$ for $1 \mathrm{~h}$. This process burned the organic matter away, but left the sclerites intact (Harvell and Suchanek, 1987). The sclerite weight fraction was calculated as the proportion of the total cortex weight consisting of sclerites (ash weight/dry weight).

\section{Statistical analyses}

All length and weight fraction distributions were normal and homoscedastic, so groups were compared using parametric tests. The "after" data from experiments I and II were subjected to split-unit (or split-plot) analysis of variance (Neter et al., 1990). Blocks, which tested for microenvironmental effects within the experimental site, consisted of pairs of adjacent racks (units), one unit being a control rack while the other was a reduced exposure (experiment I) or reduced light (experiment II) rack. Within racks, individual colonies (subunits) received the different damage treatments. Because previous work had indicated that different regions within colonies may differ in sclerite composition (West, 1996), mid-branch and tip regions were examined separately. Hence, for each experiment, four split-unit analyses were performed: (1) mid-branch sclerite length; (2) mid-branch sclerite weight fraction; (3) tip sclerite length; and (4) tip sclerite weight fraction. Because the Unit*Damage term was not significant in any of the analyses $(P>0.29$ in all cases), it was removed from the model and its sum of squares was pooled with the error sum of squares for final calculation of $F$-statistics (Neter et al., 1990).

Mid-branch and tip-damage responses detected in the split-unit ANOVAs were confirmed through comparison of "before" and "after" material from within damaged colonies. Both before and after measurements were taken for each mid-damaged or tip-damaged colony, and my a priori expectation was that after and before samples would differ in the same direction as would the after and control samples; hence, I analyzed the before and after data using paired one-tailed $t$-tests. Data from opposite the scars (experiment I only) were also compared to before data using a paired one-tailed $t$-test.

In both experiments, the different contrasts of interest involved multiple comparisons and contained variables that lacked independence from variables in other tests (e.g., sclerite length and sclerite weight fraction are from the same colony; control mid-branch and control tip are from the same colony). Hence, a sequential Bonferroni correction for multiple tests was performed (Holm, 
1979; Rice, 1989). The sequential Bonferroni method is less conservative and more powerful than the standard Bonferroni method yet still restricts the probability of a type-I error for the entire test as well as each step of the test to $\alpha=0.05$ (Holm, 1979; Rice, 1989).

\section{Results}

\section{Damage}

In both experiments I and II, mean sclerite length increased $23 \%$ in regenerated mid-branch scars (see Fig. 1), whereas sclerite weight fraction decreased $2.3 \%$ (Fig. 3). The increase in sclerite length was significant for the after and control comparisons of the split-unit ANOVAs (Tables I, II) as well as for the before and after paired comparisons (Fig. 3A). Mean sclerite weight fraction de-

\section{MID-BRANCH RESPONSE}
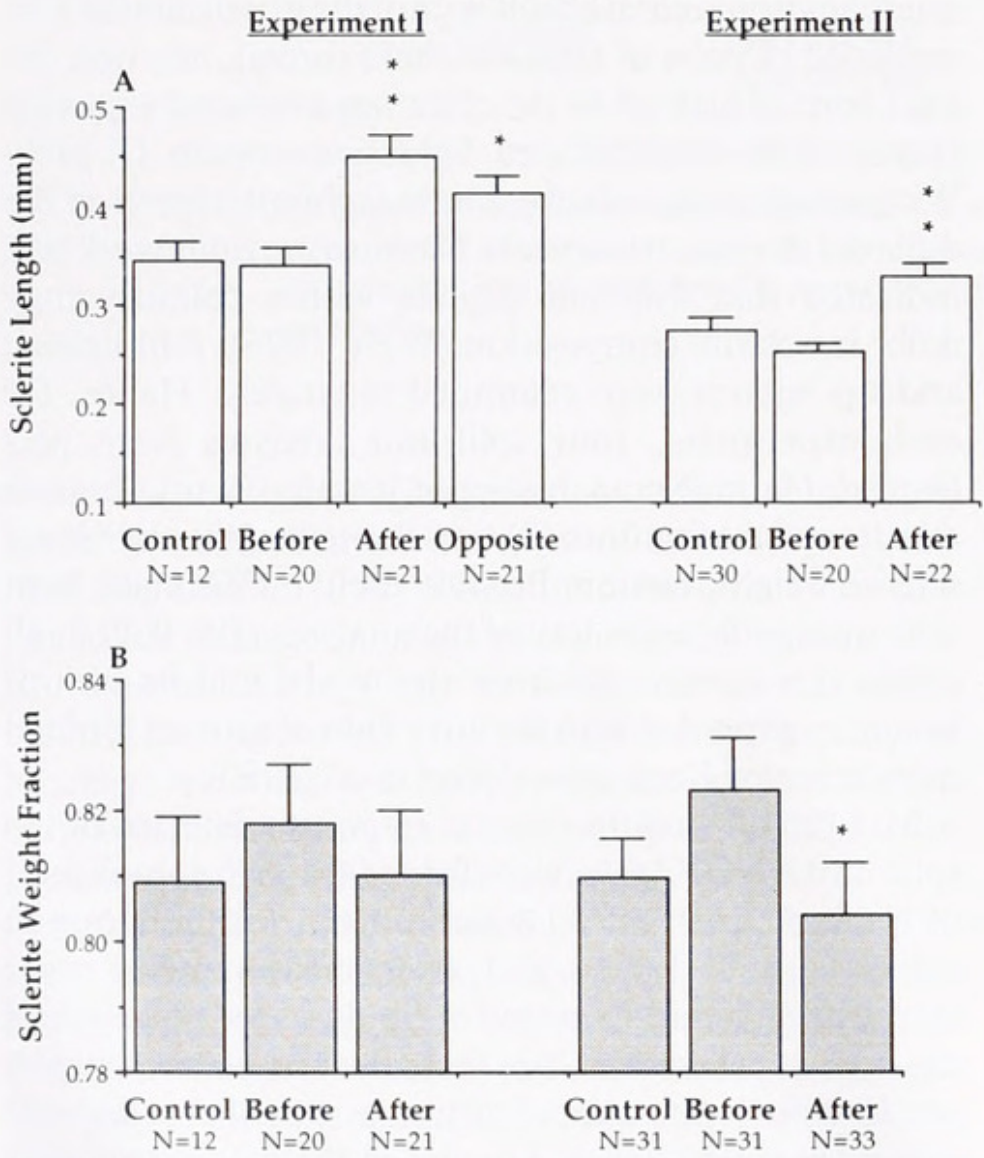

Figure 3. Briareum asbestinum. Response of colony mid-branch regions to simulated predator damage: $(A)$ mean sclerite lengths $(\mathrm{mm})$; and (B) mean sclerite weight fractions. Error bars are 1 standard error. Groups: control = undamaged mid-branch tissue at end of experiment; before $=$ original mid-branch tissue gouged at start of experiment; after $=$ regenerated mid-branch scar tissue at end of experiment; opposite $=$ tissue from opposite the scar, sampled at the end of the experiment. The sample sizes for paired $t$-tests are indicated by the $n$ values of the before groups. Under sequential Bonferroni adjustment, ${ }^{* *}$ denotes significance of both the control versus after group comparison and the before versus after paired $t$-test; ${ }^{*}$ denotes significance of the paired $t$ test only.

\section{Table I}

Summary of split-unit analyses of variance on sclerite length and sclerite weight fraction for Briareum asbestinum in experiment I (June-August 1991)

\begin{tabular}{llll}
\hline \hline & & \multicolumn{2}{c}{$P$ value } \\
\cline { 3 - 4 } $\begin{array}{c}\text { Comparison } \\
\text { region }\end{array}$ & \multicolumn{1}{c}{ Source } & Length & Wt. fraction \\
\hline \multirow{2}{*}{ Tip } & Block & 0.954 & 0.040 \\
& Exposure & 0.465 & 0.294 \\
& Block*Exposure & 0.201 & 0.946 \\
Mid-branch & Damage & 0.062 & 0.742 \\
& Block & 0.284 & 0.340 \\
& Exposure & 0.388 & 0.240 \\
& Block*Exposure & 0.663 & 0.896 \\
& Damage & $0.005^{*}$ & 0.939 \\
\hline
\end{tabular}

Note: Tip region: comparison of protected to exposed colony tips and comparison of damaged colony tips to undamaged control tips; midbranch region: comparison of protected to exposed mid-regions and comparison of damaged colony mid-regions to undamaged control mid-regions. Blocks (pairs of adjacent racks) test for microenvironmental effects. *denotes significance under sequential Bonferroni adjustment.

creased in cortex material after scar damage, but the effect was statistically significant only for the before and after comparison of experiment II (Tables I, II; Fig. 3B). Thus, simulated predator damage did alter the average lengths and (in one case) the average weight fractions of $B$. asbestinum sclerites. Moreover, the mid-branch increase in sclerite length was not restricted to newly formed cortex material within the healed scars. Sclerites

Table II

Summary of split-unit analyses of variance on sclerite length and sclerite weight fraction for Briareum asbestinum in experiment II (February-April 1991)

\begin{tabular}{llll}
\hline \hline \multirow{2}{*}{$\begin{array}{c}\text { Comparison } \\
\text { region }\end{array}$} & \multicolumn{1}{c}{ Source } & \multicolumn{2}{c}{$P$ value } \\
\cline { 3 - 4 } Tip & Block & Length & Wt. fraction \\
& Shading & 0.870 & 0.294 \\
& Block*Shading & 0.977 & 0.433 \\
Mid-branch & Damage & 0.286 & 0.126 \\
& Block & $0.665^{*}$ & 0.971 \\
& Shading & 0.191 & 0.532 \\
& Block*Shading & 0.348 & 0.865 \\
& Damage & $0.003^{*}$ & 0.092 \\
\hline
\end{tabular}

Note: Tip region: comparison of shaded to unshaded colony tips and comparison of damaged colony tips to undamaged control tips; midbranch region: comparison of shaded to unshaded mid-regions and comparison of damaged colony mid-regions to undamaged control mid-regions. Blocks (pairs of adjacent racks) test for microenvironmental effects. *denotes significance under sequential Bonferroni adjustment. 
from material opposite the scar were also significantly longer than the sclerites before damage (Fig. 3A), indicating that this length response was regionwide.

The response to tip removal was opposite to that of mid-branch scarring. Colonies subjected to tip amputation produced new tips that contained sclerites that were up to $16 \%$ shorter and made up $2.5 \%$ more of the total cortex weight (Fig. 4). The significant difference between tips after damage and control tips is reflected in the damage term of the split-unit ANOVA for experiment II (Table IIA). The difference between damaged tips and controls was not statistically significant in experiment I (Table IA; Fig. 4A). However, within colonies, both experiments showed a significant decrease in sclerite length from before to after damage (Fig. 4A). Increases in mean weight fraction in healed tips were statistically significant only for the before and after comparison of experiment I (Tables I, II; Fig. 4B).

\section{Water motion}

Dissolution of plaster of Paris domes over $24 \mathrm{~h}$ showed that water motion inside the walled racks was significantly reduced compared to water motion within control racks $(P=0.01$, unpaired $t$ test; Fig. 5). The magnitude of the reduction was similar to water-motion differences measured for colonies growing within crevices versus on the open reef flat at a variety of sites around San Salvador (Fig. 5). Such microhabitat differences have been correlated with significant sclerite variation, with microprotected colonies containing longer sclerites at lower densities than microexposed colonies (West, 1996).

When colonies from a shallow site of high-energy waves and surge were shielded from water motion within the walled racks, their sclerites did not differ from the sclerites of control colonies after 9 weeks. This result was consistent for both mid-branch and tip regions of colonies (Table I). In summary, the skeletal composition of Briareum asbestinum colonies was not modified in response to the degree and duration of water-motion reductions tested here.

\section{Light}

In experiment II, shallow-water colonies were subjected to greatly reduced light levels by shading them with dark screens that had been previously determined to reduce the light levels typical of $12 \mathrm{~m}$ to those typical of $30 \mathrm{~m}$ (J. Miles, pers. comm.). After 14 weeks, shaded colonies did not differ significantly from unshaded controls in either sclerite length or sclerite weight fraction. This result was consistent for both mid-branch and tip regions of colonies (Table II). Thus, as with water motion, there was no indication that the light reductions

\section{TIP RESPONSE}
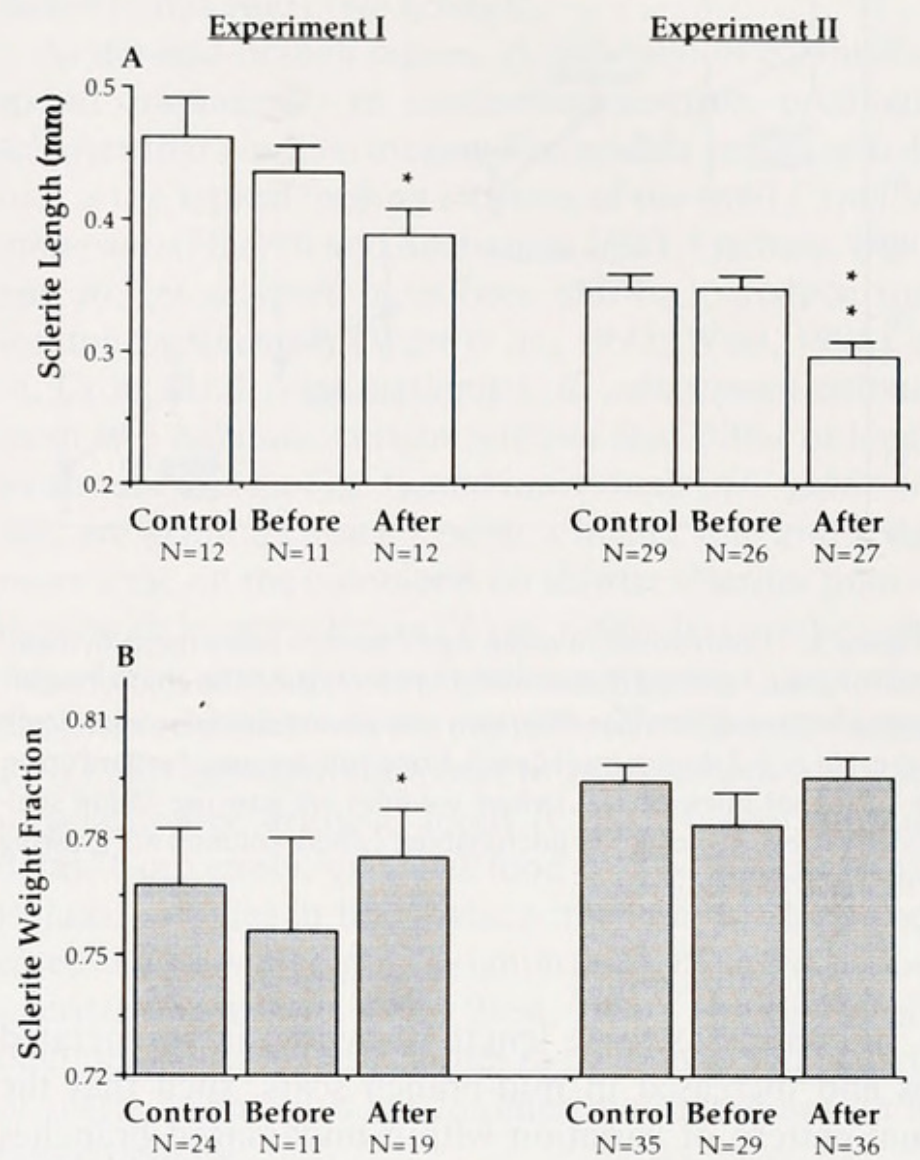

Figure 4. Briareum asbestinum. Response of colony tip regions to simulated predator damage: (A) mean sclerite lengths ( $\mathrm{mm}$ ); and (B) mean sclerite weight fractions. Error bars are 1 standard error. Groups: control $=$ undamaged tips at end of experiment; before $=$ original tips amputated at start of experiment; after = regenerated tips at end of experiment. The sample sizes for paired $t$-tests are indicated by the $n$ values of the before groups. Under sequential Bonferroni adjustment, ${ }^{* *}$ denotes significance of both the control versus after group comparison and the before versus after paired $t$-test; ${ }^{*}$ denotes significance of the paired $t$-test only.

tested in this experiment triggered a plastic response in sclerite composition.

\section{Discussion}

\section{Environmental cues}

Briareum asbestinum colonies responded to one of the three types of environmental cues tested in this study. Simulated predator damage caused clear and significant changes in sclerite morphology, and these changes actually reversed patterns of sclerite length that were observed in colonies without mid-branch or tip damage. Samples collected from naturally growing colonies in the field display a consistent pattern in which the sclerites are longer at the tips of colonies than at the basal regions; similarly, the experimental controls contained longer sclerites at the tips than at the mid-branch regions (Fig. 


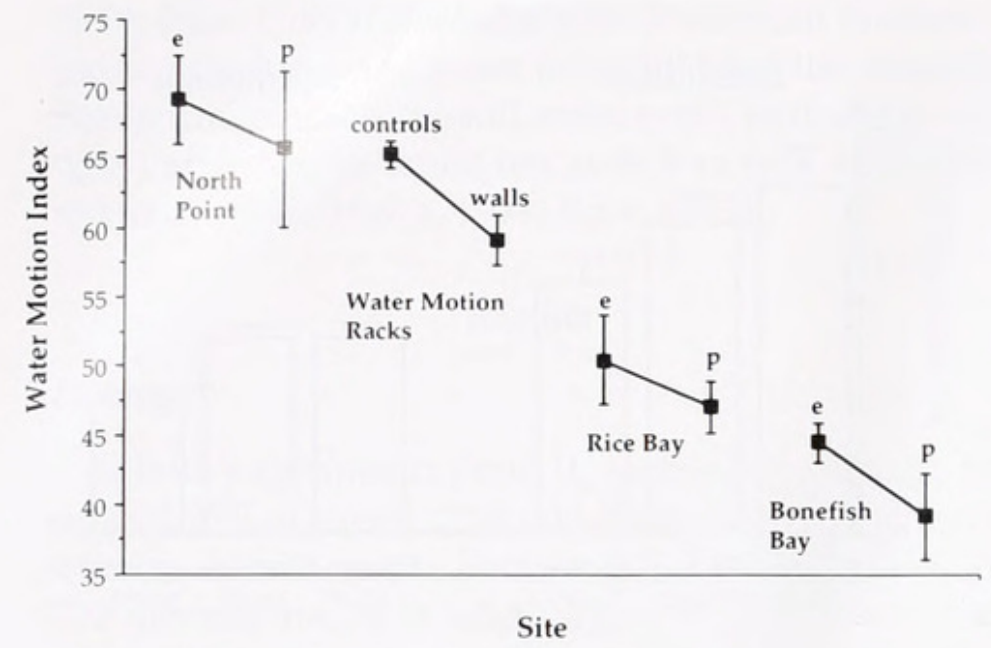

Figure 5. Comparison of mean water-motion index (percent dissolution of plaster of Paris domes over $24 \mathrm{~h}$ ) for walled and control experimental racks and for other Briareum asbestinum sites of similar depth ( $1-4 \mathrm{~m})(n=4-5$ domes in all cases). Error bars are one standard error $\mathrm{p}=$ protected microhabitat (where colonies are growing within sheltered crevices), $\mathrm{e}=$ exposed microhabitat (where colonies are growing on the open reef flat).

6). In contrast, sclerite length decreased in regenerated tips and increased in mid-branch scars, such that the usual pattern of variation within undamaged branches was fully reversed (Fig. 6). Furthermore, sclerite length increased not only within mid-branch scars, but also in material located on the opposite side of the colony from the actual wound. Hence, this is a regionwide response that likely affects the entire band of cortex material surrounding a scar.

These mid-region increases in mean sclerite length are more likely due to sclerite turnover than to the simple addition of many long sclerites. If the average length of sclerites was shifted by the accumulation of very long sclerites without the loss of any small sclerites, then we would expect to see greater variances associated with scar means than with control means and higher sclerite weight fractions within scars than in controls. Instead, scarred colonies have length variances that are comparable to controls, and they have reduced weight fractions (Fig. 3).

In general, the changes in sclerite weight fraction reflected the previously observed negative correlation between sclerite length and sclerite density. Weight fraction tended to decrease as sclerite length increased within healed scars, and the opposite was true for regenerated tips: however, for each region (tip and mid-branch), the damage-induced change in weight fraction was statistically significant for only one out of six contrasts tested. Nevertheless, the significant weight fraction responses that were detected, when combined with the dramatic and consistent changes in sclerite length (16\%-23\%) observed, provide strong evidence of plasticity.
In contrast to the damage responses, there was no indication that the sclerites of shallow-water colonies were altered in response to the abiotic cues of reduced water motion or reduced light. Depth-related sclerite variation may therefore include a component of genetic differentiation. With its ability to reproduce asexually through fragmentation (Brazeau, 1989) and its brooded, negatively buoyant larvae (Brazeau and Lasker, 1990), B. asbestinum is probably relatively philopatric. Indeed, an electrophoretic study performed concurrently with this work indicates significant genetic differentiation between shallow and deep populations (Brazeau and Harvell, 1994). Yet there is also some indication that sclerites are altered in response to wounds that mimic breakage (see discussion below), and reciprocal transplantation revealed a plastic change in sclerites with very extreme differences in depth (West et al., 1993). Here, I tested the more usual variation in light and water motion that colonies in highly populated shallower environments encounter. As such, the exposure and light treatments applied to $B$. asbestinum over 9-14 weeks did not induce significant changes in sclerite length or sclerite weight fraction. Further testing is warranted to determine whether a longer duration of acclimation could eventually result in plastic shifts in sclerite composition.

\section{Ecological and evolutionary implications}

When colony tips regenerate, the new cortex contains sclerites of decreased length and increased weight frac-

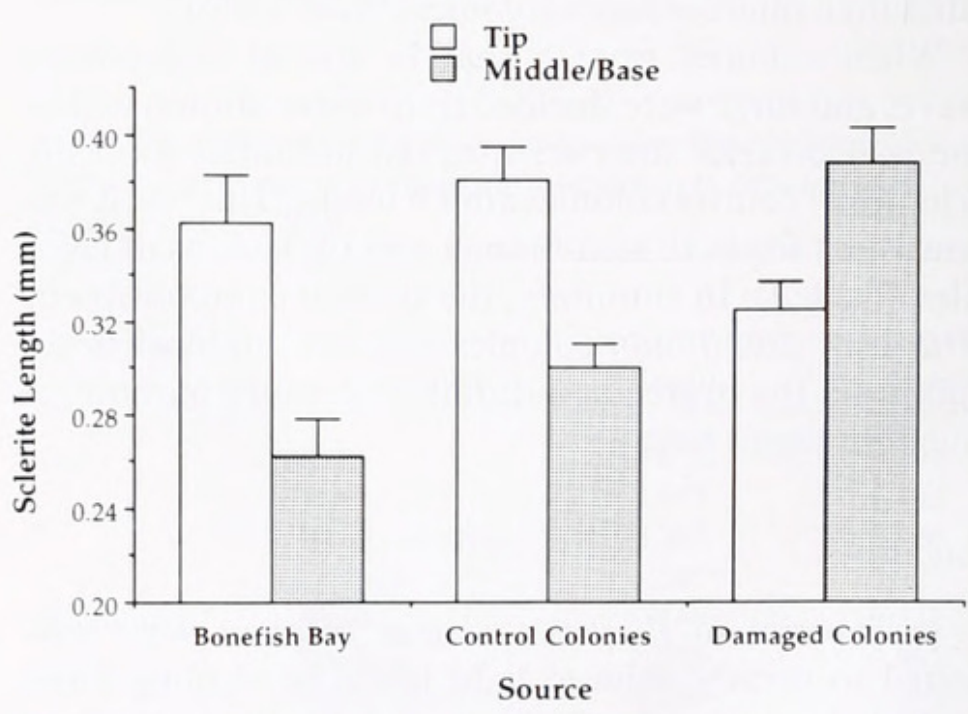

Figure 6. Briareum asbestinum. Comparison of mean sclerite length $(\mathrm{mm})$ in different regions of naturally growing colonies versus experimental colonies. Source groups: Bonefish Bay $=$ samples from tip and base regions of colonies $(n=16)$ growing naturally near the transplant sites, Control Colonies $=$ samples from tip $(n=41)$ and midbranch $(n=42)$ regions of pooled experimental controls, Damaged Colonies $=$ samples from regenerated tips $(n=39)$ and healed mid-branch scars $(n=43)$ of pooled damage treatments. Error bars are 1 standard error. 
tion. Since tip amputation is a characteristic feeding mode of the worm Hermodice carunculata, then perhaps increased sclerite densities are an induced defense that makes feeding difficult for worms, or renders the food less palatable (Vreeland and Lasker, 1989). This hypothesis seems unlikely for the following reasons. First, $H$. carunculata does not feed exclusively on colony tips, but also feeds on middle regions of $B$. asbestinum branches (Vreeland and Lasker, 1989) where the response to damage is a decrease in sclerite density. Second, Vreeland and Lasker (1989) found no relationship in this predator between preferences for particular gorgonian species and the ash content (sclerite density) of those species. Finally, $H$. carunculata routinely feeds on milleporid fire corals (Witman, 1988), and one hungry worm in the laboratory attempted to engulf the tip of a plastic pen cap (pers. obs.). Hence, a $2.5 \%$ increase in sclerite weight fraction at colony tips would probably be a poor defense against this predator.

Instead, the plasticity of sclerites in colony tips after amputation may be a response that decreases further breakage. Survival is lower for small fragments than for larger fragments in other gorgonians (Lasker, 1990), thus breakage of $B$. asbestinum colonies may result in partial mortality as water motion abrades loose branch fragments against the reef. In addition, Gerhart (1990) found that fouling by epibionts such as algae is a serious problem for gorgonian colonies that have suffered major damage such as the baring of large wounded areas at scars or break points. For these reasons, it may be advantageous for colonies to cover such wounds with new cortex material that is fortified against further breakage through increased packing of smaller sclerites.

Biomechanical assays using both artificial and real tissues have indicated that small sclerites at high densities confer greater stiffness than longer and more sparsely packed sclerites (Koehl, 1982). This may be because small sclerites at high densities provide more surface area for tissue attachment and also leave smaller spaces consisting solely of deformable soft matrix. In more recent work, Koehl (1996) has also shown that the strength and toughness of sclerite-reinforced materials increasesand then decreases-with increasing sclerite density. Biomechanical testing of actual B. asbestinum branches is needed to determine whether the tip response renders the surrounding matrix stronger and tougher, or more brittle and breakable. A finding of increased strength and toughness in regenerated tips would support the hypothesis that the observed sclerite modifications function in colony reinforcement. This hypothesis could be further tested by breaking additional colonies at the mid-branch region instead of the tip region and observing their response. To adopt a fortification response of shorter, denser sclerites at mid-branch, colonies would have to be capable of reversing the scar-induced sclerite shifts detected in this study (see below).

At the mid-branch region, B. asbestinum colonies respond dramatically to mechanical scarring, producing sclerites that are $23 \%$ longer. The middle region of colonies is the typical feeding location of the snail Cyphoma gibbosum (Harvell and Suchanek, 1987; Gerhart, 1990), and longer sclerites have been shown to reduce snail feeding significantly (West $e t$ al., 1993; West, 1996). At St. Croix (U.S. Virgin Islands), B. asbestinum colonies from two habitats contain sclerites that differ in length by about $22 \%$ (see Fig. 1), and individuals of C. gibbosum that are given a choice feed at a higher rate and spend more time on the colonies with shorter sclerites than on those with longer sclerites (West, 1996). It is unlikely that this effect is due solely to chemistry because $C$. gibbosum has gorgonian-detoxifying enzymes (Vrolijk and Targett, 1992) and appears indifferent to B. asbestinum extracts in sclerite-free artificial foods (C. D. Harvell, unpubl. data). Conversely, artificial food assays that employed isolated sclerites in the absence of chemistry have indicated that this predator is significantly deterred by long sclerites (West et al., 1993; West, 1996). Hence, the production of $23 \%$ longer sclerites in the mid-branch regions of scarred San Salvador colonies may represent an induced defense.

Harvell (1984) hypothesized that predator-induced defenses should be favored in clonal taxa that suffer intermittent, unpredictable nonfatal encounters with predators. Cyphoma gibbosum frequently causes significant damage to colonies of B. asbestinum, but it seldom completely kills them (Kinzie, 1970; Birkeland and Gregory, 1975). At shallow sites of greatest snail activity, the average amount of surface area scarred per B. asbestinum colony can approach $30 \%$ (West, 1996). Although the tenure time of individual C. gibbosum on particular gorgonian colonies averages only about 10 days (Harvell and Suchanek, 1987), snails tend to form aggregations that have been observed to stay together in a localized area (and even on a single colony) for up to 4 months (Kinzie, 1970; Birkeland and Gregory, 1975; Hazlett and Bach, 1982; Gerhart, 1986). Therefore, colonies within such a feeding area may be grazed upon multiple times, by multiple snails, over a period of weeks to months. Meanwhile, B. asbestinum in areas adjacent to large snail aggregations may be virtually free of predator damage (pers. obs.). Experiments on feeding behavior have shown that when given a choice, $C$. gibbosum tends to move off of colonies containing long sclerites and onto colonies containing short sclerites (West, 1996). Therefore, production of snail-deterrent sclerites by B. asbest $i$ num, occurring over a period of months, would be an appropriate and advantageous defensive response.

A potential cost to this induced defense may relate 
once again to the effects of changes in skeletal composition on the biomechanical behavior of colonies. Tissues that contain long sclerites at low densities will be less stiff and more elastic than tissues with short sclerites at high densities. In the region of a shift to long, sparse sclerites, a branch will indeed be in little danger of breaking due to brittleness; yet too great a propensity for pliability might itself be disadvantageous. A branch that is too soft may not be able to support the optimal orientation for light or prey capture, and excessive bending and swaying of the colony in waves and surge could lead to damage as tissue is abraded against adjacent coral heads. If so, this may explain why long sclerites are an induced rather than a constitutive defense.

The evolution of adaptive plasticity is favored in many plants and corals because of their distributions across changing habitats and their inability to escape extreme environmental conditions through movement (Bradshaw, 1965). In plants, inducible chemical and morphological defenses against predators have been widely reported (Schultz, 1988). In colonial invertebrates such as bryozoans, gorgonians, and scleractinians, it is morphological defenses against competitors rather than against predators that have been most widely documented (Adler and Harvell, 1990). Examples of predator-induced defenses have been uncommon in colonial invertebrates and have been cited only for temperate bryozoans (Harvell, 1984). Now, $B$ asbestinum may represent a new example of a tropical colonial invertebrate with an inducible defense against a predator. Another gorgonian (Plexaurella dichotoma) also responds to snail damage by increasing both the size and density of its sclerites (Nowlis, West, and May, unpubl. data). These results for two different genera of gorgonians suggest that the functioning of sclerites as an inducible defense may be widespread in this order of corals.

\section{Acknowledgments}

This project benefited from suggestions and field assistance from C. D. Harvell, A.-M. Walls, D. F. Shapiro, J. Nowis. S. Lewis, and S. Nolon. Statistical advice was provided L. Buttel and S. J. Schwager. I thank C. D. Harvell, M. Geber, N. J. Hairston, Jr., R. Strathmann, the FHL discussion group, and two anonymous reviewers for constructive comments on the manuscript. This research was supported by grants from the Mellon Foundation, the American Museum of Natural History, the Houston Underwater Dive Club (Seaspace), Sigma Xi Grants-in-Aid of Research (national chapter), and the Cornell Graduate School to J. M. West, and NSF grant OCE 90-012034 to C. D. Harvell.

\section{Literature Cited}

Adler, F. R., and C. D. Harvell. 1990. Inducible defenses, phenotypic variability and biotic environments. TREE 5(12): 407-410.
Baldwin, I. T., and T. E. Ohnmeiss. 1993. Alkaloidal responses to damage in Nicotiana native to North America. J. Chem. Ecol. 19(6): 1143-1153.

Barnes R. D. 1987. Invertebrate Zoology. Saunders, New York.

Bavestrello, G., M. Bonito, and M. Sara. 1993. Influence of depth on the size of sponge spicules. Sci. Ma. 57(4): 415-420.

Birkeland, C., and B. Gregory. 1975. Foraging behavior and rates of feeding of the gastropod, Cyphoma gibbosum. Bull. Nat. Hist. Mus. Los Angeles Co. 20: 57-67.

Bradshaw, A. D. 1965. Evolutionary significance of phenotypic plasticity in plants. $A d v$. Genet. 13: 115-155.

Bradshaw, A. D. 1974. Environment and phenotypic plasticity. Brookhaven Symp. Biol. 25: 75-94.

Brazeau, D. A. 1989. A male-biased sex ratio in the Caribbean octocoral, Briareum asbestinum: sex ratio evolution in clonal organisms. Doctoral Dissertation, State University of New York at Buffalo, NY

Brazeau, D. A., and C. D. Harvell. 1994. Genetic structure of local populations and divergence between growth forms in a clonal invertebrate, the Caribbean octocoral Briareum asbestinum. Mar. Biol. 104: 465-474

Brazeau, D. A., and H. R. Lasker. 1990. Sexual reproduction and external brooding by the Caribbean gorgonian Briareum asbestinum. Mar. Biol. 104: 465-474.

Bushek, D. 1988. Settlement as a major determinant of intertidal oyster and barnacle distributions along a horizontal gradient. J. Exp. Mar. Biol. Ecol 122: 1-18.

Day, R. W. 1977. The ecology of settling organisms of the coral reef at Heron Island, Queensland. Doctoral Dissertation, University of Sydney, Australia.

de Weerdt, W.H. 1981. Transplantation experiments with Caribbean Millepora species, including some ecological observations on growth forms. Bijdr. Dierkd. 51: 1-9.

Doty, M.S. 1971. Measurement of water movement in reference to benthic algal growth. Bot. Mar. 14: 32-35.

Foster, A. B. 1979. Phenotypic plasticity in the reef corals Montastraea annularis (Ellis \& Solander) and Siderastrea siderea (Ellis \& Solander). J. Exp. Mar. Biol. Ecol. 39: 25-54.

Francis, L. 1973. Intraspecific aggression and its effects on the distribution of Anthopleura elegantissima and some related anemones. Biol. Bull. 144: 73-92

Gerhart, D. J. 1986. Gregariousness in the gorgonian-eating gastropod Cyphoma gibbosum: tests of several possible causes. Mar. Ecol. Prog. Ser. 31: 255-263.

Gerhart, D. J. 1990. Fouling and gastropod predation: consequences of grazing for a tropical octocoral. Mar. Ecol. Prog. Ser. 62: 103-108.

Gilbert, J. J., and R. S. Stemberger. 1984. Asplanchna-induced polymorphism in the rotifer Keratella slacki. Limnol. Oceanogr. 29: 1309-1316.

Grigg, R. W. 1972. Orientation and growth form of sea fans. Limnol Oceanogr. 17(2): 185-192.

Harlan, J. R. 1945. Cleistogamy and chasmogamy in Bromus carinatus Hook, and Arn. Am. J. Bot. 32: 66-72.

Harvell, C. D. 1984. Predator-induced defense in a marine bryozoan. Science 224: 1357-1359.

Harvell, C. D., and D. Padilla. 1990. Inducible morphology, heterochrony and size hierarchies in a colonial invertebrate monoculture. Proc. Natl. Acad. Sci. USA 87: 508-512.

Harvell, C. D., and T. S. Suchanek. 1987. Partial predation on tropical gorgonians by Cyphoma gibbosum (Gastropoda). Mar. Ecol. Prog. Ser. 38: 37-44.

Havel, J. 1986. Predator-induced defenses: a review. Pp. 263-278 in Predation: Direct and Indirect Impacts on Aquatic Communities, 
W. C. Kerfoot and A. Sih, eds. University Press of New England, Hanover, $\mathrm{NH}$.

Hazlett, B. A., and C. E. Bach. 1982. Distribution pattern of the Flamingo Tongue Shell (Cyphoma gibbosum) on its gorgonian prey (Briareum asbestinum). Mar. Behav. Physiol. 8: 305-309.

Holm, S. 1979. A simple sequentially rejective multiple test procedure. Scand. J. Stat. 6: 65-70.

Ivker, F. 1972. A hierarchy of histo-incompatibility in Hydractinia echinata. Biol. Bull. 143: 162-174.

Jokiel, P. L., and J. I. Morrissey. 1993. Water motion on coral reefs: evaluation of the 'clod card' technique. Mar. Ecol. Prog. Ser. 93: 175-181.

Kinzie, R. A. 1970. The ecology of the gorgonians (Cnidaria: Octocorallia) of Discovery Bay, Jamaica. Doctoral Dissertation, Yale University, New Haven, CT.

Koehl, M. A. R. 1982. Mechanical design of spicule-reinforced tissue: stiffness. J. Exp. Biol. 98: 239-267.

Koehl, M. A. R. 1996. Mechanical design of sclerite-reinforced skeletons. Am. Zool. 36(5): 55A.

Lang, J. C. 1973. Interspecific aggression by scleractinian corals. II. Why the race is not only to the swift. Bull. Mar. Sci. 23: 260-279.

Lasker, H. R. 1990. Clonal propagation and population dynamics of a gorgonian coral. Ecology 71(4): 1578-1589.

Lasker, H. R., and M. A. Coffroth. 1988. Temporal and spatial variability among grazers: variability in the distribution of the gastropod Cyphoma gibbosum on octocorals. Mar. Ecol. Prog. Ser. 43: 285-295.

Lasker, H. R., M. A. Coffroth, and L. M. Fitzgerald. 1988. Foraging patterns of Cyphoma gibbosum on octocorals: the roles of host choice and feeding preference. Bull. Mar. Biol. Lab. Woods Hole 174: 254-266.

Lesser, M. P., V. M. Weis, M. R. Patterson, and P. L. Jokiel. 1994. Effects of morphology and water motion on carbon delivery and productivity in the reef coral, Pocillopora damicornis (Linnaeus): diffusion barriers, inorganic carbon limitation, and biochemical plasticity. J. Exp. Mar. Biol. Ecol. 178: 153-179.

Lewis, S. M., J. N. Norris, and R. B. Searles. 1987. The regulation of morphological plasticity in tropical reef algae by herbivory. Ecology 68(3): 636-641

McCloskey, L. R., and L. Muscatine. 1984. Production and respiration in the Red Sea coral Stylophora pistillata as a function of depth. Proc. R. Soc. Lond. Ser. B 222: 215-230.

McNaughton, S. J., and J. L. Tarrants. 1985. Grass leaf silicification: natural selection for an inducible defence against herbivores. Proc Natl. Acad. Sci. USA 80: 790-791.

Meacham, C. A., and T. Duncan. 1990. Morphosys version 1.26. University Herbarium, University of California, Berkeley, CA.

Miles, J. 1991. Inducible agonistic structures in the tropical corallimorpharian, Discoma sanctithomae. Biol. Bull. 180: 406-415.

Mooney, H. A., and M. West. 1964. Photosynthetic acclimation of plants of diverse origin. Am. J. Bot. 51: 825-827.

Muscatine, L. 1974. Endosymbiosis of cnidarians and algae. Pp. 359395 in Coelenterate Biology, L. Muscatine and H. M. Lenhoff, eds. Academic Press, New York.

Muscatine, L., R. R. Pool, and R. K. Trench. 1975. Symbiosis of algae and invertebrates: aspects of the symbiont surface and the hostsymbiont interface. Trans. Am. Microsc. Soc. 94(4): 450-469.

Muus, B. J. 1968. A field method for measuring "exposure" by means of plaster balls. Sarsia 34: 61-68.

Neter, J., W. Wasserman, and M. H. Kutner. 1990. Applied Linear Statistical Models. Richard D. Irwin, Inc., Boston, MA

Palumbi, S. R. 1986. How body plans limit acclimation: responses of a demosponge to wave force. Ecology 67(1): 208-214.

Pawlik, J. R., M. T. Burch, and W. Fenical. 1987. Patterns of chemical defense among Caribbean gorgonian corals: a preliminary survey. J. Exp. Mar. Biol. Ecol. 108: 55-66.
Rice, W. 1989. Analyzing tables of statistical tests. Evolution 43(1): 223-225.

Roy, J., and H. A. Mooney. 1982. Physiological adaptation and plasticity to water stress of coastal and desert populations of Heliotropium curassavicum. Oecologia 52: 370-375.

Scheiner, S. M. 1993. Genetics and evolution of phenotypic plasticity. Annu. Rev. Ecol. Syst. 24: 35-68.

Schlichting, C. D. 1986. The evolution of phenotypic plasticity in plants. Annu. Rev. Ecol. Syst. 17: 667-693.

Schultz, J. C. 1988. Plant responses induced by herbivores. TREE 3(2): 45-49

Sebens, K. P. 1984. Water flow and coral colony size: interhabitat comparisons of the octocoral Alcyonium siderium. Proc. Natl. Acad. Sci. USA 81: 5473-5477.

Sebens, K. P. 1987. Coelenterata. Pp. 55-120 in Animal Energetics, T. J. Pandian and F. J. Vernberg, eds. Academic Press, San Diego, CA.

Sebens, K. P., and J. C. Miles. 1988. Sweeper tentacles in a gorgonian octocoral: morphological modifications for interference competition. Biol. Bull. 175: 378-387.

Sorensen, T. 1954. Adaptation of small plants to deficient nutrition and a short growing season. Illustrated by cultivation experiments with Capsella bursapastoris (L). Med. Botan. Tidsskrift 51: 339-361.

Stearns, S. C. 1989. The evolutionary significance of phenotypic plasticity. Bioscience 39(7): 436-445

Svoboda, A. 1978. In situ monitoring of oxygen production and respiration in Cnidaria with and without zooxanthellae. Pp. 75-82 in Physiology and Behavior of Marine Organisms, D. S. McLusky and A. J. Berry, eds. Permagon Press, New York.

Turesson, G. 1920. The cause of plagiotrophy in maritime shore plants. Lunds Univ. Arsskr. Avd. 2 (NF) 16(2): 1-33.

Van Alstyne, K. L. 1988. Herbivore grazing increases polyphenolic defenses in the intertidal brown alga Fucus distichus. Ecology 69(3): 655-663.

Van Alstyne, K. L., and V. J. Paul. 1992. Chemical and structural defenses in the sea fan Gorgonia ventalina: effects against generalist and specialist predators. Coral Reefs 11: 155-159.

Via, S., and R. Lande. 1985. Genotype-environment interaction and the evolution of phenotypic plasticity. Evolution 39(3): 505-522.

Vreeland, H. V., and H. R. Lasker. 1989. Selective feeding of the polychaete Hermodice carunculata Pallas on Caribbean gorgonians. J. Exp. Mar. Biol. Ecol. 129: 265-277.

Vrolijk, N. H., and N. M. Targett. 1992. Biotransformation enzymes in Cyphoma gibbosum (Gastropoda: Ovulidae): implications for detoxification of gorgonian allelochemicals. Mar. Ecol. Prog. Ser. 88: $237-246$.

Wainwright, S. A., W. D. Biggs, J. D. Currey, and J. M. Gosline. 1976. Mechanical Design in Organisms. Edward Arnold, London.

Wellington, G. M. 1980. Reversal of digestive interactions between Pacific reef corals: mediation by sweeper tentacles. Oecologia 47: 340-343.

West, J. M. 1996. Skeletal variation in the Caribbean coral Briareum asbestinum (Gorgonacea): pattern and process across environmental gradients. Doctoral Dissertation, Cornell University, Ithaca, NY

West, J. M., C. D. Harvell, and A.-M. Walls. 1993. Morphological plasticity in a gorgonian coral (Briareum asbestinum) over a depth cline. Mar. Ecol. Prog. Ser. 94: 61-69.

Wijsman-Best, M. 1974. Habitat-induced modification of reef corals (Faviidae) and its consequences for taxonomy. Proc. 2nd Int. Coral Reef Symp. 2: 217-228.

Witman, J. D. 1988. Effects of predation by the fire worm Hermodice carunculata on milleporid hydrocorals. Bull. Mar. Sci. 42: 446-458.

Young, T.P. 1987. Increased thorn length in Acacia depranolobium - an induced response to grazing. Oecologia 71: 436-438. 


\section{$2 \mathrm{BHL}$ Biodiversity Heritage Library}

West, Jordan M. 1997. "Plasticity in the Sclerites of a Gorgonian Coral: Tests of Water Motion, Light Level, and Damage Cues." The Biological bulletin 192, 279-289. https://doi.org/10.2307/1542721.

View This Item Online: https://www.biodiversitylibrary.org/item/17361

DOI: https://doi.org/10.2307/1542721

Permalink: https://www.biodiversitylibrary.org/partpdf/32086

\section{Holding Institution}

MBLWHOI Library

\section{Sponsored by}

MBLWHOI Library

\section{Copyright \& Reuse}

Copyright Status: In copyright. Digitized with the permission of the rights holder.

License: http://creativecommons.org/licenses/by-nc-sa/3.0/

Rights: https://biodiversitylibrary.org/permissions

This document was created from content at the Biodiversity Heritage Library, the world's largest open access digital library for biodiversity literature and archives. Visit BHL at https://www.biodiversitylibrary.org. 